\title{
Factors Affecting E-shopping Behaviour of College Students in Gujarat
}

\author{
*Bhavna P. Bosamia \\ * Ph D Research Scholar, School of Commerce, Gujarat University, Ahmedabad, India. \\ bbkhatri.75@gmail.com
}

\begin{abstract}
Promotion of digital India and due to uphold benefits of e-shopping; online market is observing constant growth in India. End of 2019 has faced global disease of COVIND 19 which has highly affected world economy. The lockdown period observed closing of traditional i.e. local market as the only solution to avoid spreading of COVIND 19 was to follow social distancing. Although online business exists the then period taught every firm big or small to do business through e-market. Thus online shopping rate increased during lockdown period as per reports given by periodicals and news channel. Therefore this study will give input for factors that affect E-shopping behavior especially for college students in Gujarat. The study was based on opinion of respondents collected through structured questionnaire which were filled by students of Gujarat University and Hemchandracharya North Gujarat University. Both descriptive analysis and inferential analysis were considered for the study. The findings of the study identified personal examination of products, worried of fraud while giving debit card/credit card information and also have fear of misuse for personal information shared on e-shopping sites as major barriers for e-shopping. Motivating factors identified were that e-shopping saves time, is convenient and it provides very attractive festival offers. The study concluded that motivating factors for online shopping have significant effect on e-shopping behavior. Satisfaction for eshopping also moderately affects e-shopping decision.
\end{abstract}

Keywords : E-shopping behavior, college students, satisfaction, barriers and motivators

\section{INTRODUCTION}

Marketing scenario is dynamic and has observed constant change from barter system to digital market. Increasing use of technology has changed the behavior, lifestyle and requirement of people. Borderless market has bought world closure and due to technology higher living standard is observed in rural area too. Many research undertaken for online market has observe growth ot ecommerce in tier II and tier III cities of India due to branded product and increased shipping facility for this area. Also findings of many research identified mostly youngster purchase online because of their technological literacy. But online shopping is growing at a faster rate in Asian countries especially India.

In order to serve customer with better accuracy usage of Artificial Intelligence has increased in ecommerce firm ensuring higher level of accuracy that e-retailer can give to its customer, also it is being observed that online services are well managed by many service units of India which include Indian Railway, Electricity Board, Banks, movie theatre etc., this has lead to promotion of other units of ecommerce like retail sector, industrial sector etc. Busy life schedule is also one of the factors that have influenced retail market of ecommerce. The growth of ecommerce is dissimilar all over the country and also differences are being observed between rural and urban areas. Considering this background an attempt to identify how people of Gujarat reacts specifically focusing college students of Gujarat to ecommerce market will be studied in current research.

\section{LiterATURE REVIEW}

Sarika Shivaji Pawar, Dinkar Khashaba More and Sarang Shankar Bhola (Aug., 2014) attempted to identify motivating factors and resisting factors that affects online buying decision. Ease of shopping is identified as important motivator and post purchase process risk is important barriers for online shopping. The findings of the research reveals gender differences for goods purchased online but gender association was not observed for amount spend on e-shopping.

Francisca N Mapiye Dube, Richard Asiedu \& Allan Phir3 (Dec., 2018) in their study attempted to know decision and consumer factors that encourages international college students of China for online shopping. The finding of the study reveals that price, product variety, convenience, Chinese language barriers are the factors that influences students to purchase online. In order to increase 
market share e-shopping firm should give more personalization and consumer socialization options on its website that can help to grow their business.

Farah, G. A., Ahmad M., Muqarrab H., Turi J. A., \& Bashir S. ( April, 2018) undertook the study to know MUST university business faculty students' online buying behavior and most influencing factor for e-shopping. Most common products purchased online by respondents include computer, electronic and mobile. Significant relationship was observed between data reliability and influencing factors for online shopping. Privacy, perceived value, firm reputation and trust are important variables identified in the study.

Vilasini Jadhav \& Monica Khanna (April, 2016) identified factors that influences online purchasing among college students in Mumbai. Influencing factors recognized includes availability, low price, promotions, comparison, convenience, customer service, perceived ease of use, attitude, time consciousness, trust and variety seeking. Goods purchased online frequently includes Tickets, electronic goods accessories, apparels, books, electronic goods, footwear, instant recharge of cell phone, gifting items. Most popular site were Flipkart and Myntra.

T. Jukariya and R. Singhvi (2018) examined important variables that affect online buying motives of students of MPUAT, Udaipur, Rajasthan through questionnaire method. Among 23 variables measured it was found that transaction security and multiple payment options, personal privacy and security, Product price and quality, the speed of access and after - sales service are important variables that affects online buying decision of respondents.

Narges Delafrooz, Laily $\mathbf{H j}$. Paim and Ali Khatibi (June, 2010) students' attitude for online shopping was measured using five point likert scale by applying multiple regression analysis. The significant factor influencing buying decision of students in Malaysia covered utilitarian orientation, convenience, price, and a wider selection. Therefore study is demanding user friendly web site that can enhance shopping market.

Pawan Kumar , Kanchan (2017) attitude of students of Ludhiana for online shopping was studied. The research attempted to identify impact of different factors for online shopping behavior of students. Factors influencing online purchase among students do not observed any association between education qualifications of respondents.

\section{Objective}

To identify relationship between online shopping behavior and various affecting factors (Satisfaction, Barriers and Motivators)

\section{Hypothesis}

H0 : There is no significant linear relationship between online shopping behavior and various affecting factors (Satisfaction, Barriers and Motivators)

H1 : There is significant linear relationship between online shopping behavior and various affecting factors (Satisfaction, Barriers and Motivators)

\section{METHODOLOGY}

The current study is descriptive and analytical, is based on primary as well as secondary data. Books, journals, different web sites, articles, published data etc. were used to study different parameters that affect e-shopping behaviour of customers. Primary data was collected through structured questionnaire and overall 1000 students from Gujarat University and Hemchandracharya North Gujarat University comprises of sample data. Both descriptive and inferential statistics were used for the study. The output is generated by using SPSS 20. Pearson correlation analysis is used to identify factors affecting e-shopping behaviour.

Table 1 : Descriptive Statistics for Online Shopping Behaviour

\begin{tabular}{|l|l|l|l|l|}
\hline \multicolumn{1}{|c|}{ Factors } & \multicolumn{1}{|c|}{ N } & \multicolumn{1}{|c|}{ Mean } & \multicolumn{1}{|c|}{ Rank } & Std. Deviation \\
\hline Online shopping is popular in India & 1000 & 3.9960 & III & .91259 \\
\hline Online shops provide good quality products & 1000 & 3.6460 & V & .97243 \\
\hline Online shopping gives comfort/enjoyment to consumers & 1000 & 3.8600 & IV & .92804 \\
\hline Mostly young generation do online shopping & 1000 & 4.1310 & I & .91579 \\
\hline e-marketing helps in modernization of India & 1000 & 4.0760 & II & .90942 \\
\hline
\end{tabular}

The above Table 1 exhibits descriptive analysis of Likert five point scale for respondents opinion with respect to online shopping. Majority of them agreed that young generation do online shopping followed by it helps in modernization of India and is becoming popular in India.

Table 2 : Descriptive Statistics for Satisfaction Level

\begin{tabular}{|c|c|c|c|c|}
\hline Factors & $\mathrm{N}$ & Mean & Rank & Std. Deviation \\
\hline Price & 687 & 4.0291 & II & .74566 \\
\hline Quality & 687 & 3.8675 & III & .79809 \\
\hline Shipping Period & 687 & 3.7118 & $\mathrm{~V}$ & .89127 \\
\hline Range of Products & 687 & 3.8428 & IV & .85461 \\
\hline Gifts Offers & 687 & 3.6754 & VI & 1.03059 \\
\hline Payment Facility & 687 & 4.0844 & I & .79823 \\
\hline Discount Coupens & 687 & 3.6201 & VII & 1.06757 \\
\hline
\end{tabular}


Based on Likert five point analysis satisfaction from online shopping reveals that high degree of satisfaction is derived from payment facility provided by e-retailer followed by price and quality of products.

Table 3 : Descriptive Statistics for Online Purchase Barriers

\begin{tabular}{|c|c|c|c|c|}
\hline $\begin{array}{rr}\text { Factors } \\
\end{array}$ & $\mathrm{N}$ & Mean & Rank & Std. Deviation \\
\hline Don't have debit card/credit card & 1000 & 3.4560 & IX & 1.27424 \\
\hline Fear of fraud while giving debit card/credit card number & 1000 & 3.8810 & II & 1.14724 \\
\hline Don't like to give personal information & 1000 & 3.8400 & III & 1.09982 \\
\hline Don't want to purchase from unfamiliar vendor & 1000 & 3.6980 & VI & 1.18245 \\
\hline Enjoy going out for shopping & 1000 & 3.6650 & VII & 1.15243 \\
\hline See/touch the product before purchasing & 1000 & 3.9740 & $\mathrm{I}$ & 1.07540 \\
\hline Slow internet & 1000 & 3.4170 & XI & 1.21268 \\
\hline Worried about cost of returning & 1000 & 3.7290 & $\mathrm{~V}$ & 1.10579 \\
\hline Delivery cost are too high & 1000 & 3.6390 & VIII & 1.11711 \\
\hline Prices are too high & 1000 & 3.4360 & $\mathrm{X}$ & 1.15466 \\
\hline Do not find product of my choice on internet & 1000 & 3.2050 & XIV & 1.19767 \\
\hline Uncomfortable about purchasing through internet & 1000 & 3.2720 & XIII & 1.20061 \\
\hline Process is expensive due to cost of access & 1000 & 3.2910 & XII & 1.17546 \\
\hline Fear of facing spamming or internet fraud & 1000 & 3.7360 & IV & 1.12942 \\
\hline Valid N (listwise) & 687 & & & \\
\hline
\end{tabular}

Different parameters identified from literature study revealed that respondents prefer traditional shopping because they like to personally examine the product before purchasing other important barriers according to the opinion of respondents is they are afraid of fraud while giving debit card/credit card number followed by they are reluctant to share personal information.

Table 4 : Descriptive Statistics for Online Purchase Motivators

\begin{tabular}{|l|c|c|c|c|}
\hline \multicolumn{1}{|c|}{ Factors } & $\mathrm{N}$ & Mean & Rank & Std. Deviation \\
\hline Convenience & 1000 & 4.2560 & II & .77270 \\
\hline Saves time & 1000 & 4.3020 & I & .78576 \\
\hline Wide range of product & 1000 & 4.0730 & $\mathrm{~V}$ & .88343 \\
\hline Product/price comparison possibility & 1000 & 3.8000 & XII & 1.02521 \\
\hline 24*7 shopping possibility & 1000 & 4.0990 & IV & .96857 \\
\hline Offers and discounts provided by e-shopping firm & 1000 & 4.0020 & VII & .91806 \\
\hline Special festival offers & 1000 & 4.2500 & III & .83198 \\
\hline Free shipping facility & 1000 & 3.9120 & IX & 1.02826 \\
\hline Friends/Relatives opinion & 1000 & 3.8310 & X & .94939 \\
\hline Different payment options with cash back offers & 1000 & 4.0320 & VI & .93694 \\
\hline Availability of customer review about product & 1000 & 3.9310 & VII & .92795 \\
\hline Cheaper internet facility & 1000 & 3.8200 & XI & \\
\hline Valid N (listwise) & 687 & & & \\
\hline
\end{tabular}

Comparing different motivational variables for online shopping it was found that most affecting motivational factor for online shopping is that it saves time followed by convenience and festival offers given by e-retailers.

Table 5 : Descriptive Statistics of Compute Variables for different parameters affecting E-shopping

\begin{tabular}{|l|l|l|}
\hline \multicolumn{1}{|c|}{ Factors } & \multicolumn{1}{c|}{ Mean } & Std. Deviation \\
\hline E-Shopping Behaviour & 3.9418 & .69864 \\
\hline Satisfaction from E-shopping & 3.8330 & .55758 \\
\hline Barriers to E-shopping & 3.5885 & .72991 \\
\hline Motivational Factor for E-shopping & 4.0257 & .63552 \\
\hline
\end{tabular}

The above table explains overall mean for the different parameters measured in the above four tables' viz e-shopping behavior, satisfaction level from e-shopping, barriers for e-shopping and e-shopping motivators. The data are calculated by using SPSS 20 through compute variable and then analyzed for descriptive statistics.

Table 6 : Summary of Correlation Analysis

\begin{tabular}{|l|c|c|c|c|}
\hline \multicolumn{1}{|c|}{ Variables } & Correlation Coefficient & $\begin{array}{c}\text { Sig. } \\
\text { (2-tailed) }\end{array}$ & \multicolumn{1}{|c|}{$\begin{array}{c}\text { Degree of } \\
\text { Correlation }\end{array}$} \\
\hline E-shopping Behaviour, E-shopping Satisfaction & $0.449^{* *}$ & .000 & 1000 & Moderate Degree \\
\hline E-shopping Behaviour, E-shopping Barriers & $0.239^{* *}$ & .000 & 687 & Low Degree \\
\hline E-shopping Behaviour, E-shopping Motivators & $0.579^{* *}$ & .000 & 1000 & High Degree \\
\hline
\end{tabular}

**. Correlation is significant at the 0.01 level (2-tailed).

The Table 6 reveals the summary of correlation of different factors affecting online shopping which were identified based on the literature study and all the factors viz satisfaction level from e-shopping, barriers for e-shopping 
and e-shopping motivators were used to identify its effect on e-shopping behavior of respondents through correlation analysis. From the above table it can be judged that most affecting factor for online shopping is e-shopping motivators having high degree of correlation with behavioral parameters followed by e-satisfaction level having moderate correlation with behavioral parameters and purchase barriers have lower degree of impact on eshopping behavior.

\section{Conclusion}

The study focused on various factors that affect online shopping behavior of college students of Gujarat. The belief and perception of student's exhibit that generally young generation are involved in online shopping, also they believe that ecommerce market contributed in modernization of India and in recent past online shopping activity is getting popular in India. Considering satisfaction it was found that payment facility, price and quality revealed higher level of satisfaction. Major barriers for eshopping includes personal examination of products, worried of fraud while giving debit card/credit card information and also have fear of misuse for personal information shared on e-shopping sites. Motivating factors identified were that e-shopping saves time, is convenient and it provides very attractive festival offers. Correlating all the affecting factors under study with behavioral aspects the most relating factor identified was motivating factor exhibiting high degree of correlation followed by satisfaction level with moderate degree of correlation and barriers have very low degree of correlation. Therefore eretailer must concentrate more on motivating factors and satisfaction level of consumer to retain and attract more business.
Consumer Research Journal, 33(November 2016), 1924. Retrieved from http://www.iiste.org/Journals/index.php/JMCR/article/ viewFile/36179/37175

[6] Stores, E., Benefits, S., Of, F., Study, T. H. E., Back, V., Certificates, G., ... Palvia, P. C. (2012). Electronic Shopping: A Paradigm Shift in Buying Behaviour among Indian Consumers, 19(1258), 1-268.

[7] AHMAD, M. (2018). Online Shopping Behavior Among University Students: Case Study of Must University. Advances in Social Sciences Research Journal, 5(4). https://doi.org/10.14738/assrj.54.4429

[8] Ankaram, S. . (2013). Indian Streams. Indian Streams Research Journal, 3(10), 4-11. https://doi.org/10.9780/2249-894X/362014/652

[9] Asiedu, R., \& Phiri, A. (2018). Factors Affecting Online Shopping Behavior of International College Students in China. International Journal of Recent Trends in Engineering and Research, 4(12), 18-29. https://doi.org/10.23883/ijrter.2018.4418.ugwyz

[10]Everitt, S. L. (2004). A Handbook of Statistical Analyses Using SPSS. Newyork: Chapman \& Hall/CRC Press Company.

[11] Kothari, C. R. (2004). Research Methodology Methods and Techniques. New Delhi: New Age International Publisher.

[12] Nandgopal R., K. A. (2008). Research Methods in Business. New Delhi: Excel Books.

[13] Robert, H. (2006). Handbook of Univariate and Multivariate Data ANalysis and Interpretation with SPSS. NewYork: Chapman \& Hall/CRC Press Company

\section{REFERENCES}

[1] Delafrooz, N., Paim, L. H., \& Khatibi, A. (2010). Students' Online Shopping Behavior: An Empirical Study. Journal of American ScienceJournal of American Science, 66(11), 137-147.

[2] Jadhav, V., \& Khanna, M. (2016). Factors influencing online buying behavior of college students: A qualitative analysis. Qualitative Report, 21(1), 1-15.

[3] Jain, D. (2015). Factors Influencing Student' s Decision Making towards Online Shopping. Pacific Business Review International, 8(3), 24-36. Retrieved from http://www.pbr.co.in/September2015/3.pdf

[4] Jukariya, T., \& Singhvi, R. (2018). A Study of Factors Affecting Online Buying Behavior of Students. International Journal of Current Microbiology and Applied Sciences, 7(1), 2558-2565. https://doi.org/10.20546/ijcmas.2018.701.308

[5] Kumar, P., \& Kanchan. (2017). Online Shopping Behaviour among Students with Special Reference to Ludhiana, Punjab, India. Journal of Marketing and 